\title{
THIN LAYER DRYING OF NILE TILAPIA FINGERLINGS USING MECHANICAL DRYER
}

\author{
Mohamed A. Basiouny ${ }^{1}$
}

\begin{abstract}
In this study, the drying experiments were conducted on fresh fingerlings of Nile tilapia, which does not benefit the consumers (non-marketed and juvenile fish), for production of the fishmeal to be used as an ingredient in feedstuffs in the aquaculture, dairy, and poultry industries. The thin layer drying behaviour of Nile tilapia fingerlings was experimentally investigated in a mechanical dryer and the mathematical modeling by using two thin layer drying models (simple and modified simple exponential models). The butane-gas was used as heat energy source for the dryer. The impact of the drying air temperature $\left(50,60,70\right.$ and $\left.80^{\circ} \mathrm{C}\right)$ and hot air velocity $(0.5,1.0$ and $1.5 \mathrm{~m} / \mathrm{s})$ on the fish moisture losses against drying time has been studied. Drying rate, moisture ratio, cost estimation and microbial assays of the drying process were also considered. The obtained data showed that, the shortest drying time of the fish was recorded at 140min with $80^{\circ} \mathrm{C}$ drying air temperature and $1.5 \mathrm{~m} / \mathrm{s}$ air velocity. While, the longest drying time was recorded at $280 \mathrm{~min}$ with $50^{\circ} \mathrm{C}$ and $0.5 \mathrm{~m} / \mathrm{s}$ treatments. Tilapia moisture content decreased from an initial level of about $84.56 \%($ d.b.) to range between 9.18 and $11.86 \%($ d.b. ) at the end drying process depending on the drying conditions. Moreover, drying rate was increased with the increase of drying air temperature and air velocity. Between the two tested models, the modified simple exponential model was found to be the most suitable for describing the drying behavior of the fish. The effects of drying air temperature and velocity on the drying constant and coefficient were also shown. On the other hands, the calculated operation cost of the dryer approaches about $2.88 \mathrm{LE} / \mathrm{kg}$ of dried whole fish. Also, the final product had a microbial count below allowed level.
\end{abstract}

${ }^{1}$ Senior researcher in Agric. Eng. Res. Inst. (AEnRI), ARC, Giza, Egypt. 


\section{INTRODUCTION}

7 ilapia has been distributed throughout the world and has become the second most important food fishes in the world. Tilapias

1 possess an impressive range of attributes that make them ideal for aquaculture. They grow rapidly, reproduce easily, adapt to a wide range of environmental conditions and accept artificial feeds readily (Watanabe et al., 2002 and Duan et al., 2005). When, the fresh fish is not utilized by consumers and converted into finished product then it remains surplus and goes waste (Jain, 2006 and Jain and Pathare, 2007). Despite its importance in contributing to national economies, health, food security and in improving the livelihoods of many artisanal fishermen in many developing countries, up to $50 \%$ of the fish harvested in the these countries is wasted (Abila, 2003). Fishmeal is an important poultry feed generally made from fish which cannot be economically utilised, fish not suitable for human consumption or fish wastes like trimmings, heads and so on and also wastes from fish canning and freezing factories. It provides digestible vitamins, minerals and proteins resulting in increased production of eggs and meat (Oyelese, 2006). Fishmeal is used widely as a feed ingredient in balanced diets for aquaculture $(150-700 \mathrm{~g} / \mathrm{kg})$ and animal production $(20-150 \mathrm{~g} / \mathrm{kg}$ ) because of its high protein content (640$700 \mathrm{~g} / \mathrm{kg}$ ) (Lagunas et al., 2005). The term fishmeal means a product obtained by drying and grinding or otherwise treating fish or fish waste to which no other matter has been added. These are semilegal definitions, and for convenience fish meal can be defined as a solid product obtained by removing most of the water and some or all of the oil from fish or fish waste. Fishmeal is generally sold as a powder, and is used mostly in compound foods for poultry, pigs and farmed fish (FAO, 1986). Tilapia is highly perishable product as it consists of up to $80 \%$ of water. Therefore, to solve the problems of high enzymatic and bacterial activity in fresh fish, the use of processing and preservation technology is necessary (Li et al., 2009 and Duan et al., 2011). Drying of fish is important, because it preserves fish by inactivating enzymes and removing the moisture necessary for bacterial and mould growth. The safe moisture content for fishmeal storage was lower than $12 \% \mathrm{db}$. It is important, for digestibility of fishmeal, to maintain moisture around the 
protein. To accomplish this it is essential to keep the maximum product temperature inside the dryers below $100^{\circ} \mathrm{C}$. If protein is overheated the amino acid structure changes. As a result the protein is not easily recognized nor absorbed by the intestines of the animals. From a practical point of view, overheating of the fishmeal makes the fishmeal less digestible. (Bala and Mondol, 2001; Bellagha et al., 2002; Duan et al., 2004; Bellagha et al., 2005 and Sobukola and Olatunde, 2011). Duan et al. (2011) used combined microwave, hot air drying for tilapia fish fillets at microwave power from 200 to $600 \mathrm{~W}$ and air temperature from 40 to $50^{\circ} \mathrm{C}$ with constant air velocity of $1.5 \mathrm{~m} / \mathrm{s}$. They found that hot airmicrowave drying technology can be used for dehydration of fresh tilapia fillets due to decrease in drying time and to improve quality (rehydration ratio). The application of dryers in developing countries can reduce losses significantly and improve the quality of dried product when it is compared to the traditional means of drying such as open sun drying. Open sun drying is not always suited to the large-scale production due to the lack of ability to control the drying conditions properly. It also requires longer drying time, which may be the cause of many complications such as uncertainties of ambient conditions, large area requirements, insect infestation or contamination with dust (Togrul and Pehlivan, 2004). Thin-layer drying models for describing the drying phenomenon of agricultural products are usually based on liquid diffusion theory (Doungporn et al., 2012). Therefore, the present study was conducted with the following objectives:

- to study the thin-layer drying characteristics of Nile tilapia fingerlings using a butan-gas dryer under different levels of drying air temperature and hot air velocity;

- to fit the experimental data obtained to semi-theoretical models widely used to describe thin-layer drying behavior of the fish;

- to estimate drying cost of the dried fish; and,

- to assay microbial of the final product.

\section{MATERIALS AND METHODS}

The experiments were carried out during the year of 2013 in Rice Mechanization Center, Meet El-Deeba, Kafrelsheikh governorate, Egypt. 


\section{Fish:}

The fresh Nile tilapia (Oreochromis niloticus) were obtained from a local fish farm in Kafrelsheikh governorate, Egypt. Tilapias were immediately transported in plastic boxes containing crushed ice to the laboratory and packed in polyethylene sacks and stored at $-18^{\circ} \mathrm{C}$ until the time of an experiment. Prior any experimental run, the fish were taken out of the refrigerator and kept in the laboratory to attain ambient air temperature. On arrival at the laboratory, the weight and dimensions of a sample were measured. The average mass, length, width and thickness of a fish were $14.78 \pm 6.97 \mathrm{~g}, 8.87 \pm 1.71 \mathrm{~cm}, 3.11 \pm 0.81 \mathrm{~cm}$ and $1.34 \pm 0.27 \mathrm{~cm}$ respectively. The initial moisture content of the fish sample was determined using the oven method (at $135^{\circ} \mathrm{C}$ to constant mass) according to $A O A C, 2005$. These experiments were replicated thrice to obtain a reasonable average, and all reading expressed on dry basis. Average moisture content was found to be $84.56 \pm 0.256 \%$ (d.b.).

\section{Butane-gas dryer:}

The dryer main frame was constructed of galvanized steel materials with dimensions of $50 \mathrm{~cm}$ long, $70 \mathrm{~cm}$ wide and $100 \mathrm{~cm}$ high. The frame completely covered with $5 \mathrm{~cm}$ thick fiberglass insulation to prevent heat loss through the surface of the dryer sides. Four rubber wheels were also used for free movement of the dryer. The drying cabinet consists of four drying trays. The trays constructed from an iron frames of $70 \mathrm{~cm}$ long $\mathrm{x}$ $50 \mathrm{~cm}$ wide $\mathrm{x} 2 \mathrm{~cm}$ high. The four drying trays were supported inside the dryer cabinet in vertical. The cabinet has a $90 \mathrm{~cm} \times 60 \mathrm{~cm}$ door made from galvanized steel materials. The front face of the door was preciously sealed with a rubber seal to prevent air constrain through the drying cabinet. A butane gas heating unit was used as heat energy source for drying air. The heating unit was accommodated inside an insulated iron housing located at the base of the dryer main frame with dimensions of $40 \mathrm{~cm}$ long $\mathrm{x} 50 \mathrm{~cm}$ wide $\mathrm{x} 20 \mathrm{~cm}$ high. The heating circuit consists of stainless-steel heating cylinder with $10 \mathrm{~cm}$ diameter, $50 \mathrm{~cm}$ long and $0.4 \mathrm{~cm}$ thick. A gas nozzle was fixed at the front side of the cylinder for gas ignition and heating the cylinder surface. The drying air pass perpendicularly around the heating cylinder until reaching the required level of drying air temperature. The temperature control system was 
consisted of a precise thermostat connected to a gas solenoid valve for stopping and connecting the gas flow to the ignition nozzle. For reignition of the gas nozzle, a small tube branched from the main gas tube was fixed in a position facing the gas nozzle and kept in contentious ignition throughout the drying process. A centrifugal blower was used for air supply to the dryer. It has an electric motor with power of $1.5 \mathrm{~kW}$ (2hp). The drying air was passed on the dryer trays though a main vertical PVC pipe with one branch at the side of drying chamber. The PVC pipe and accompanied with a control valve was placed on inlet to supply the required amount of air for drying chamber. The dryer was designed and constructed by Elmesery, 2008. The schematic diagrams of the mechanical dryer are shown in Figs. 1 and 2.

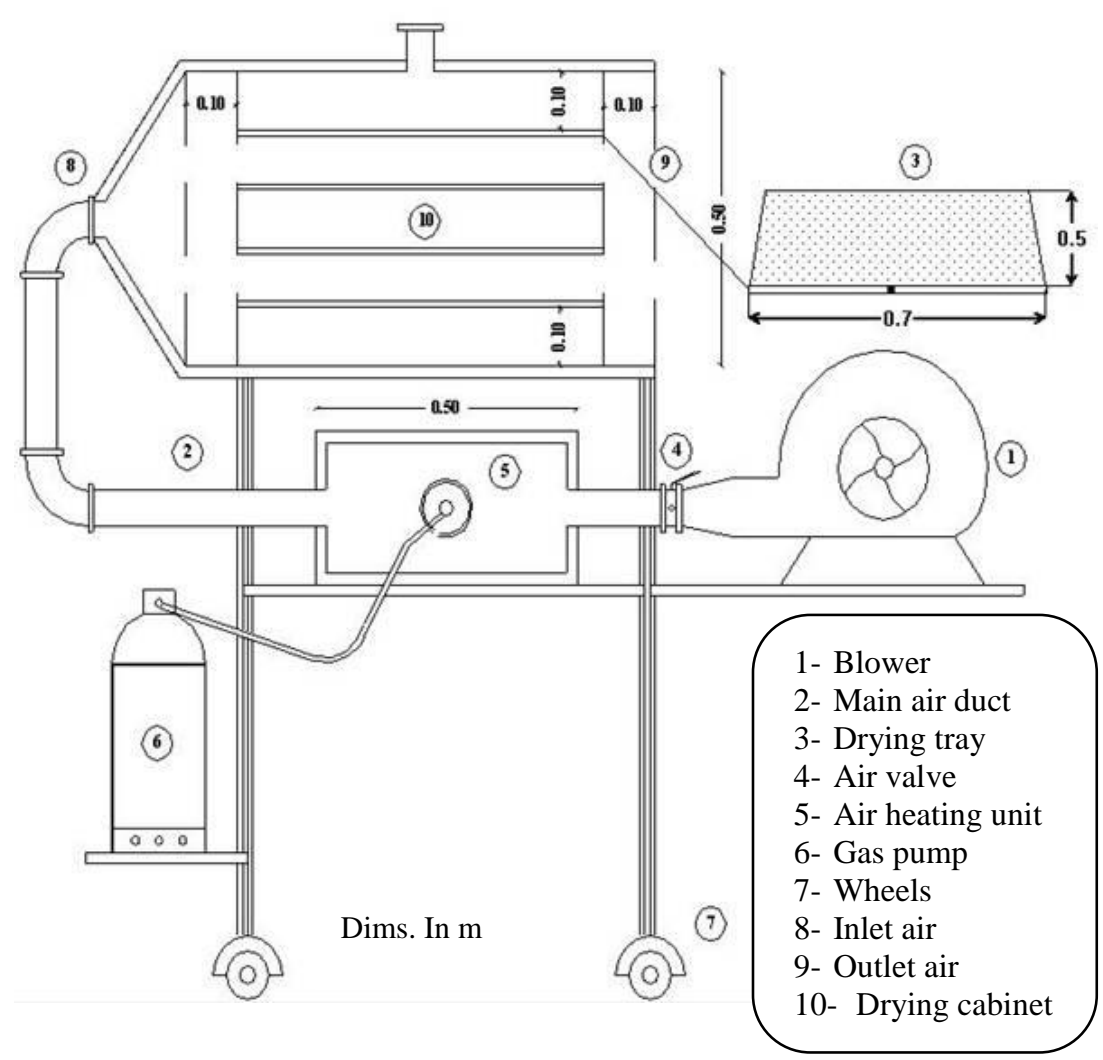

Fig. 1: Schematic diagram of the mechanical dryer. 


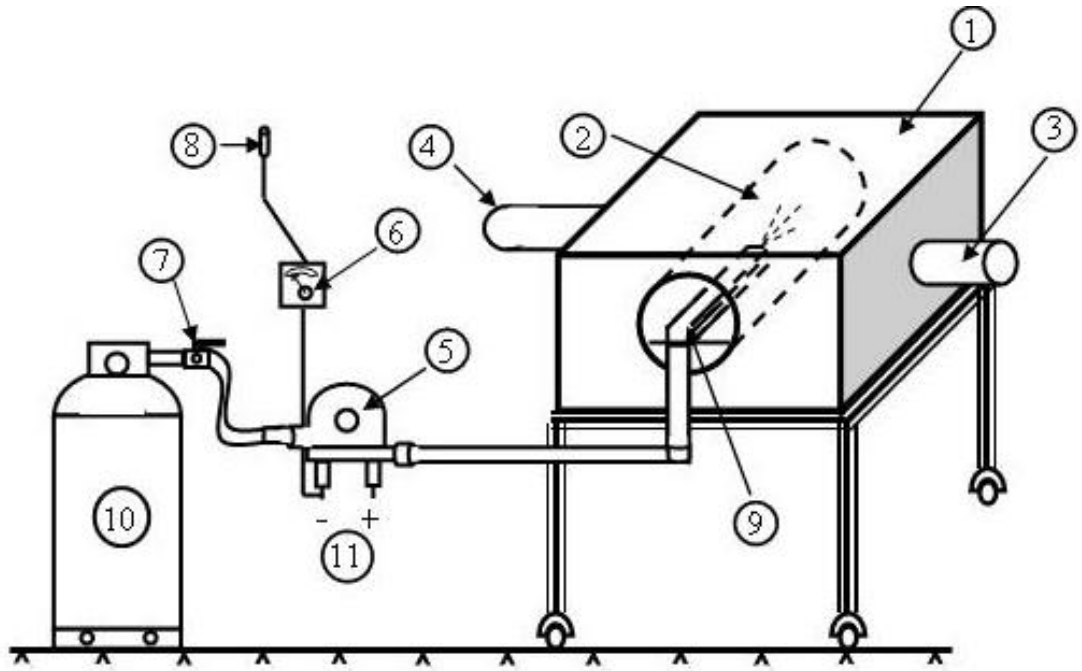

1- Heating unit.

4- Air outlet.

7- Control valve. 10- Gas pump.
2- Heating cylinder. 3- Air inlet.

5- Solenoid valve. 6- Thermostat.

8- Sensor.

9- Nozzle.

Fig. 2: Sketch of air heating unit and temperature control system.

\section{Experimental procedure:}

The drying parameters were performed at different drying air temperatures $\left(50,60,70\right.$ and $\left.80^{\circ} \mathrm{C}\right)$ and at different air velocities $(0.5,1.0$ and $1.5 \mathrm{~m} / \mathrm{s}$ ) for drying Nile tilapia in butane-gas dryer. These ranges were selected to cover all possible drying air condition, which are expected to use for drying of fish. Drying air temperature, air velocity and relative humidity were measured at different points under each tray at equal time intervals (20min) of moisture content of fish samples. Using T-type thermocouples and a digital thermometer did the measurement of the drying air temperature and fish samples. Air velocity was measured by using a digital vane-probe anemometer (Model, BREMI-BRI 5080-USA), which reads the velocity directly in $\mathrm{m} / \mathrm{s}$. The air relative humidity was continuously measured during the experimental study by hygrometer device. In each experiment, about $4 \mathrm{~kg}$ of fish 
sample was used. After the system was run for at least $25 \mathrm{~min}$ to reach steady conditions for the operation temperatures, the samples were evenly distributed within the sample tray as a single layer and dried there. Mass variations of the dried fish with time were measured by means of an electrical balance with accuracy of $0.01 \mathrm{~g}$. Moisture losses of samples were recorded at $20 \mathrm{~min}$ intervals. The moisture contents of the fish were determined at the starting and end of each run of experiments. The first and third trays were employed for measuring the change in fish moisture content at time intervals $20 \mathrm{mim}$ at the beginning of the drying process up to 280min during the last stage drying, while the second and fourth trays were used for measuring the initial and final moisture of the fish. Each run in the experiment was done in triplicate. The drying process was stopped when the moisture content of the dried samples reached to below $12 \%$ (d.b.). The dried samples were allowed to cool down at an ambient temperature for $15 \mathrm{~min}$ and then packed in polyethylene bags for the storage at laboratory temperature.

\section{Mathematical modeling of drying curves:}

The instantaneous dry basis moisture content $M_{d}$ of the tilapia fingerlings at any time was calculated as:

$$
M_{d}, \%(\text { d.b. })=\frac{m-m_{d}}{m_{d}} \times 100 \text {. }
$$

Where: $m$ is instantaneous mass and $m_{d}$ is the fully dried mass. The drying rate $D R, \% \min ^{-1}$ which is another important factor in describing characteristics of the drying process, and was defined, with dry basis moisture content, by (Fatouh et al., 2006):

$$
D R=\frac{d M_{d}}{d t}=\frac{M_{d, i}-M_{d, i+1}}{t_{i}-t_{i+1}}
$$

Where: $M_{d, i}$ and $M_{d, i+1}$ are the moisture content of the tilapia fish at the time $t_{i}$ and $t_{i+1}$ respectively. The most relevant aspects of drying technology are the mathematical modeling of the drying process and the equipment. In order to achieve a set of equations which allow a proper description of the dryer. In this study a simple exponential equation and 
modified simple exponential equation will be used to describe thin layer drying of Nile tilapia fingerlings. The simple exponential equation (Lewis, 1921):

$$
M R=\frac{M_{d}-M_{e}}{M_{o}-M_{e}}=\exp (-K t)
$$

Where: $M R$ is the moisture ratio (decimal); $M_{d}, M_{e}$ and $M_{o}(\% d . b$.$) are$ the instantaneous moisture content at any time of drying, equilibrium moisture content and initial moisture content, respectively; $K$ is the drying rate constant $\left(\mathrm{min}^{-1}\right)$ and $t$ is the drying time ( $\left.\mathrm{min}\right)$. In equation (3) the initial moisture ratio at drying time zero becomes 1 . This model in equation (3) has been applied to fit the drying data of tilapia fish, after converting its from to the logarithmic form relating the moisture ratio $(M R)$ and elapsed drying time $(t)$ as follows:

$\operatorname{Ln} M R=(-K t)$

The modified simple exponential equation (Henderson and Pabis, 1961): $M R=\frac{M_{d}-M_{e}}{M_{o}-M_{e}}=A \cdot \exp (-K t)$

Where: $A$ is the experimental constant (dimensionless). This model in equation (5) has been applied to fit the drying data after converting its form to the exponential form and calculating the constant $K$ and $A$ from relationship between $M R$ and $t$ as follows:

$$
M R=A \cdot e^{(-K t)}
$$

Using non-liner regression and considering moisture ratio $(M R)$ and drying time $(t)$ as the regression variable, the parameters $A$ and $K$ in the empirical equations (4) and (6) were determined for each set of drying conditions. The coefficient of determination $\left(r^{2}\right)$ was calculated for each model in order to test their accuracy in reproducing the 
experimental data. The higher values of the coefficient $\left(r^{2}\right)$ were chosen for goodness of fit (Akpinar et al., 2006).

\section{Total cost:}

Total cost requirements of the butan-gas dryer include fixed and variable costs as follows:

\section{A- Fixed cost:}

1- Sinking-fund method was used to determine the depreciation. This method considers the problem of depreciation as one of establishing a fund that will draw compound interest (Hunt, 1983).

$$
D=[P-S] \frac{(1+i)^{L}-(1+i)^{n}}{(1+i)^{L}-1}+S
$$

Where:

$D \quad$ depreciation and interest cost, LE/Yr;

$P \quad$ dryer purchase price, $\mathrm{LE}$;

$S \quad$ salvage rate $(0.1 P), \mathrm{LE}$;

$i \quad$ interest as compound annually (8\%), decimal;

$L \quad$ dryer life, (10Yr);

$n$ number representing age of the dryer in years at the beginning of the fifth year.

2- Taxes, insurance and shelter costs were assumed as $2 \%$ of the purchase price of the dryer.

B- Variable cost:

1- The annual charge for repairs and maintenance costs would be $80 \%$ of original price (Hunt, 1983).

2- Also, the variable costs include cost of the butan-gas, electricity and labor.

\section{Microbial assays:}

Immediately after samples cooling, The various dilutions of dried fish samples were prepared using the distilled water. The method used for microbial analysis was according to APHA, 2001. Nutrient Agar media was used to detect the total count of bacteria (aerobic plate count) and it consists of: Peptone, Yeast extract, Glucose, Agar and distilled water $(\mathrm{pH}=7.0 \pm 0.1)$. The plates of different dilution were incubated at $37^{\circ} \mathrm{C}$ for 48h. While, potatoes-dextrose Agar was used to detect the growth of 
yeast and mold and it consists of: Potatoes, Agar, Glucose and distilled water $(\mathrm{pH}=3.5 \pm 0.1)$. The plates of different dilution were incubated at $25-28^{\circ} \mathrm{C}$ for $72 \mathrm{~h}$ (Mary et. al., 2009). Results were expressed as colony forming unit/gram (cfu/g). E-coli was enumerated using the standard method of most probable number technique (APHA, 2001) and Salmonella-specific was enumerated by the pour plate method recommended by USFDA,1998. The dried fish samples were analyzed at Animal Health Research Institute Laboratories, Kafrelsheikh governorate, Egypt.

\section{RESULTS AND DISCUSSION}

\section{Fish moisture content:}

Fig. 3 shows the change in fish moisture content as related to drying time at different levels of drying air temperature and hot air velocity. General trend was observed where, the initial moisture content decreased with the increasing in drying air temperature, air velocity and drying time. The limited information is available on the kinetics of water removal from Nile tilapia fish. The decreased moisture content could be attributed to increased evaporation of water both on the surface and in the fish body due to increasing temperatures and velocities of drying air. The initial moisture content of $84.56 \% \mathrm{db}$ decreased to rang between 9.18 and $11.86 \% \mathrm{db}$ at the end drying process depending on the drying conditions. For instance, the shortest drying time was recorded at $140 \mathrm{~min}$ with $80^{\circ} \mathrm{C}$ drying air temperature and $1.5 \mathrm{~m} / \mathrm{s}$ air velocity. While, the longest drying time was recorded at $280 \mathrm{~min}$ with $50^{\circ} \mathrm{C}$ and $0.5 \mathrm{~m} / \mathrm{s}$ treatments.

\section{Drying rate:}

Fig. 4 illustrates the variation of drying rate with the change in fish moisture content at different levels of drying air temperature and hot air velocity. As shown in the figure the drying rate was increased with the increase of drying air temperature and air velocity. As a conclusions, the $80^{\circ} \mathrm{C}$ and $1.5 \mathrm{~m} / \mathrm{s}$ treatments showed the highest drying rate curve of as compared to the other treatments. On the other hand, The $50^{\circ} \mathrm{C}$ and $0.5 \mathrm{~m} / \mathrm{s}$ treatments showed the lowest drying rate curve as compared to the other treatments. The highest drying rate achieved in $80^{\circ} \mathrm{C}$ and $1.5 \mathrm{~m} / \mathrm{s}$ treatments was $0.148 \mathrm{~min}^{-1}$ while, at drying air temperatures of $50^{\circ} \mathrm{C}$ and air velocity of $0.5 \mathrm{~m} / \mathrm{s}$ was $0.049 \mathrm{~min}^{-1}$. 

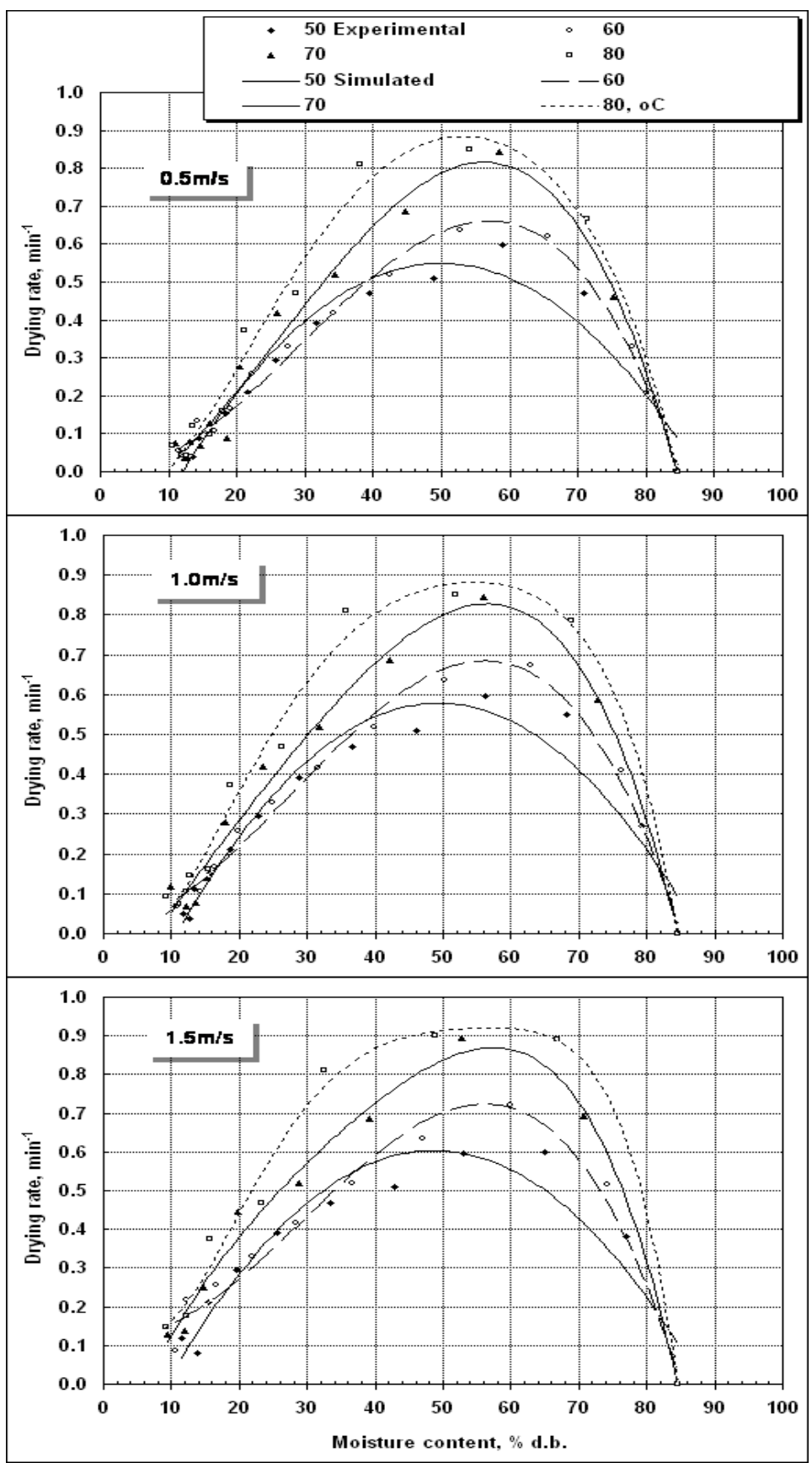

Fig. 4: Change in fish drying rate as related to moisture content at different drying air temperature and air velocity. 
For $0.5 \mathrm{~m} / \mathrm{s}$ air velocity, the drying rate curves showed falling trend beyond moisture content of $85.98,86.38,87.03$ and $87.63 \%$ at drying air temperatures of $50,60,70$ and $80^{\circ} \mathrm{C}$, respectively. While, for $1.5 \mathrm{~m} / \mathrm{s}$ air velocity, The drying rate curves showed falling trend beyond moisture content of $86.38,87.55,88.81$ and $89.14 \%$ at drying air temperatures of $50,60,70$ and $80^{\circ} \mathrm{C}$, respectively. Moreover, constant drying rate period was not observed under any of the test conditions of this investigation. The most effectual force governing the moisture movement in the fish was diffusion.

\section{Fitting of the drying curves:}

A single layer of Nile tilapia fingerlings was dried in butane-gas dryer under controlled condition of temperature and air velocity. The drying experiments were conducted for temperature range of $50-80^{\circ} \mathrm{C}$ and air velocity range of $0.5-1.5 \mathrm{~m} / \mathrm{s}$. Two drying models (simple and modified simple exponential models) have been used to describe drying curves. The model type, model constant and determination coefficient $\left(r^{2}\right)$ of two different models used for moisture ratio change with drying time are presented in Tables 1 and 2. The best model describing the thin layer drying characteristic was chosen as the one with the highest $r^{2}$ values. A nonlinear regression allowed us to fit each of the proposed models. Two models were provided an adequate fit to the experimental data with a value for $r^{2}$ of greater than 0.9419 , indicating a good fit. The modified simple model was able to present the highest $r^{2}$ values (0.9662-0.9961) at different drying conditions as compared to simple exponential model. Based on these results, the modified simple model was found to be the best fitted model to describe the drying curves in all the treatments tested. Fig. 5 suggest comparisons of the experimental and predicted moisture ratio obtained using the modified simple model with drying time of fish at different drying conditions. It can be seen from these there was a good conformity between experimental and predicted moisture ratios. This indicates the suitability of the modified simple model in describing the drying behaviour of Nile tilapia fingerlings in the hot air drying process. As shown in the Fig. 5, the experimental moisture ratio was varied from 0.0475 to 0.9434 . The drying air temperature of $80^{\circ} \mathrm{C}$ and air velocity of $1.5 \mathrm{~m} / \mathrm{s}$ achieved the lowest moisture ratio during the study period. 
Table 1: Statistical results obtained from simple model at different drying conditions.

\begin{tabular}{|c|c|c|c|c|c|c|}
\hline \multirow{2}{*}{$\begin{array}{c}\text { Drying air } \\
\text { Temp., }\end{array}$} & \multicolumn{6}{|c|}{ Cimple exponential model } \\
\cline { 2 - 7 } & \multicolumn{2}{|c|}{$\mathbf{0 . 5}$} & \multicolumn{2}{|c|}{$\mathbf{1 . 0}$} & \multicolumn{2}{c|}{$\mathbf{1 . 5}$} \\
\cline { 2 - 7 } & $K$ & $r^{2}$ & $K$ & $r^{2}$ & $K$ & $r^{2}$ \\
\hline $\mathbf{5 0}$ & 0.0119 & 0.9761 & 0.0129 & 0.9649 & 0.0141 & 0.9485 \\
\hline $\mathbf{6 0}$ & 0.0121 & 0.9887 & 0.0138 & 0.9752 & 0.0160 & 0.9419 \\
\hline $\mathbf{7 0}$ & 0.0131 & 0.9888 & 0.0156 & 0.9885 & 0.0185 & 0.9722 \\
\hline $\mathbf{8 0}$ & 0.0142 & 0.9793 & 0.0172 & 0.9947 & 0.0204 & 0.9822 \\
\hline
\end{tabular}

Table 2: Statistical results obtained from modified simple model at different drying conditions.

\begin{tabular}{|c|c|c|c|c|c|c|c|c|c|}
\hline \multirow{2}{*}{$\begin{array}{c}\text { Drying } \\
\text { air } \\
\text { Temp. } \\
{ }^{\circ} \mathrm{C}\end{array}$} & \multicolumn{6}{|c|}{ Air velocity, m/s } \\
\cline { 2 - 10 } & \multicolumn{3}{|c|}{$\mathbf{0 . 5}$} & \multicolumn{3}{|c|}{1.0} & \multicolumn{3}{c|}{$\mathbf{1 . 5}$} \\
\cline { 2 - 10 } & $A$ & $K$ & $r^{2}$ & $A$ & $K$ & $r^{2}$ & $A$ & $K$ & $r^{2}$ \\
\hline $\mathbf{5 0}$ & 1.3188 & 0.0133 & 0.9920 & 1.3548 & 0.0147 & 0.9859 & 1.3704 & 0.0163 & 0.9744 \\
\hline $\mathbf{6 0}$ & 1.1719 & 0.0130 & 0.9950 & 1.2758 & 0.0154 & 0.9899 & 1.3678 & 0.0185 & 0.9662 \\
\hline $\mathbf{7 0}$ & 1.0058 & 0.0131 & 0.9889 & 1.1367 & 0.0165 & 0.9928 & 1.2595 & 0.0206 & 0.9859 \\
\hline $\mathbf{8 0}$ & 0.9354 & 0.0138 & 0.9807 & 1.0818 & 0.0178 & 0.9944 & 1.1909 & 0.0221 & 0.9961 \\
\hline
\end{tabular}

\section{Total cost:}

Drying cost for the butan-gas dryer was estimated for drying fish from an initial moisture content of about $84.56 \% \mathrm{db}$ to a final moisture content of about $9.18 \% \mathrm{db}$ using a drying air temperature of $80^{\circ} \mathrm{C}$ and hot air velocity of $1.5 \mathrm{~m} / \mathrm{s}$. The assumptions used in cost estimation and obtained results are presented in Table 3. As shown in the table, the estimated total cost of fish drying using the dryer was $3.82 \mathrm{LE} / \mathrm{h}$, while the drying cost per $\mathrm{kg}$ of fresh fish was $0.72 \mathrm{LE}$. Since, the total capacity of the dryer is of about $16 \mathrm{~kg}$ of fresh fish producing of about $4 \mathrm{~kg}$ of dried fish, the calculated operation cost of the dryer approaches of about $2.88 \mathrm{LE} / \mathrm{kg}$ of dried fish. 

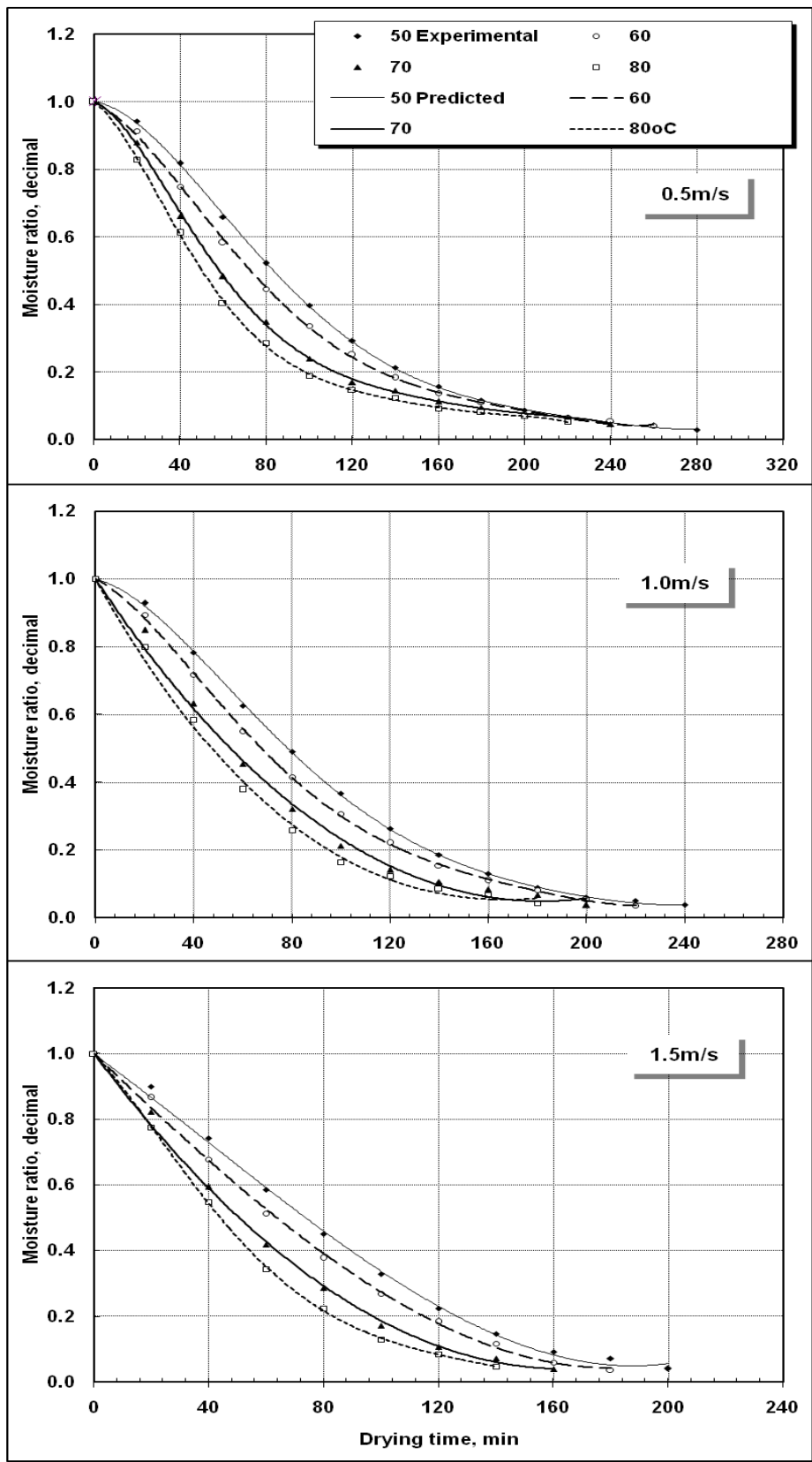

Fig. 5: Comparison of the experimental and predicted moisture ratio obtained using the modified simple model with drying time of fish at different drying conditions. 
Table 3: Cost estimation for the butan-gas dryer*.

\begin{tabular}{|c|c|}
\hline Assumptions: & \\
\hline $\begin{array}{l}\text { Price of the dryer, } \mathrm{LE} \\
\text { Dryer capacity fresh fish, } \mathrm{kg} \\
\text { Drying time, } \mathrm{hr} \\
\text { Number of drying runs, run } \backslash \mathrm{Yr} \\
\text { Operation hours, } \mathrm{h} / \mathrm{Yr} \\
\text { Total mass of fresh fish, } \mathrm{kg} \backslash \mathrm{Yr}\end{array}$ & $\begin{array}{l}2500 \\
16 \\
3 \\
600 \\
1800 \\
9600 \\
\end{array}$ \\
\hline $\begin{array}{l}\text { Total fixed cost, } \boldsymbol{L E} / \mathbf{h} \\
\text { Depreciation and interest cost, LE/h } \\
\text { Taxes, insurance and shelter, LE/h }\end{array}$ & $\begin{array}{l}0.9105 \\
0.8827 \\
0.0278 \\
\end{array}$ \\
\hline $\begin{array}{l}\text { Total Variable cost, } \boldsymbol{L E} / \mathbf{h} \\
\text { Repair and maintenance cost, LE/h } \\
\text { Butan-gas cost, LE/h } \\
\text { Electricity cost, LE/h } \\
\text { Labor cost, LE/h } \\
\end{array}$ & $\begin{array}{l}2.9086 \\
0.1111 \\
0.1091 \\
0.6884 \\
2 \\
\end{array}$ \\
\hline $\begin{array}{l}\text { Total cost: } \\
\text { LE/h } \\
\text { LE/run } \\
\text { LE/kg, fresh fish } \\
\text { LE/kg, dried fish }\end{array}$ & $\begin{array}{l}3.82 \\
11.46 \\
0.72 \\
2.88\end{array}$ \\
\hline
\end{tabular}

* Drying air temperature $\left(80^{\circ} \mathrm{C}\right)$ and air velocity $(1.5 \mathrm{~m} / \mathrm{s})$.

\section{Microbial assays:}

Results of total bacterial count, yeast and mould in dried fish at all the drying conditions are shown in Fig. 6. The number of microorganism is shown on a logarithm scale. From this histogram, the lowest values of total bacterial counts, yeast and mould in dried fish were 2.48 and $2.87 \log \mathrm{cfu} / \mathrm{g}$ at drying air temperature of $80^{\circ} \mathrm{C}$ and air velocity of $1.5 \mathrm{~m} / \mathrm{s}$, respectively. While, the highest values of the same previous microorganisms in dried fish were 3.08 and $5.0 \log \mathrm{cfu} / \mathrm{g}$ at $50^{\circ} \mathrm{C}$ and $0.5 \mathrm{~m} / \mathrm{s}$ treatments, respectively. For all drying conditions, the final product had a microbial count below allowed level. This results agree with APHA, 2001. Also, results showed that, the final product was free from E-coli and salmonella with all the drying conditions. 


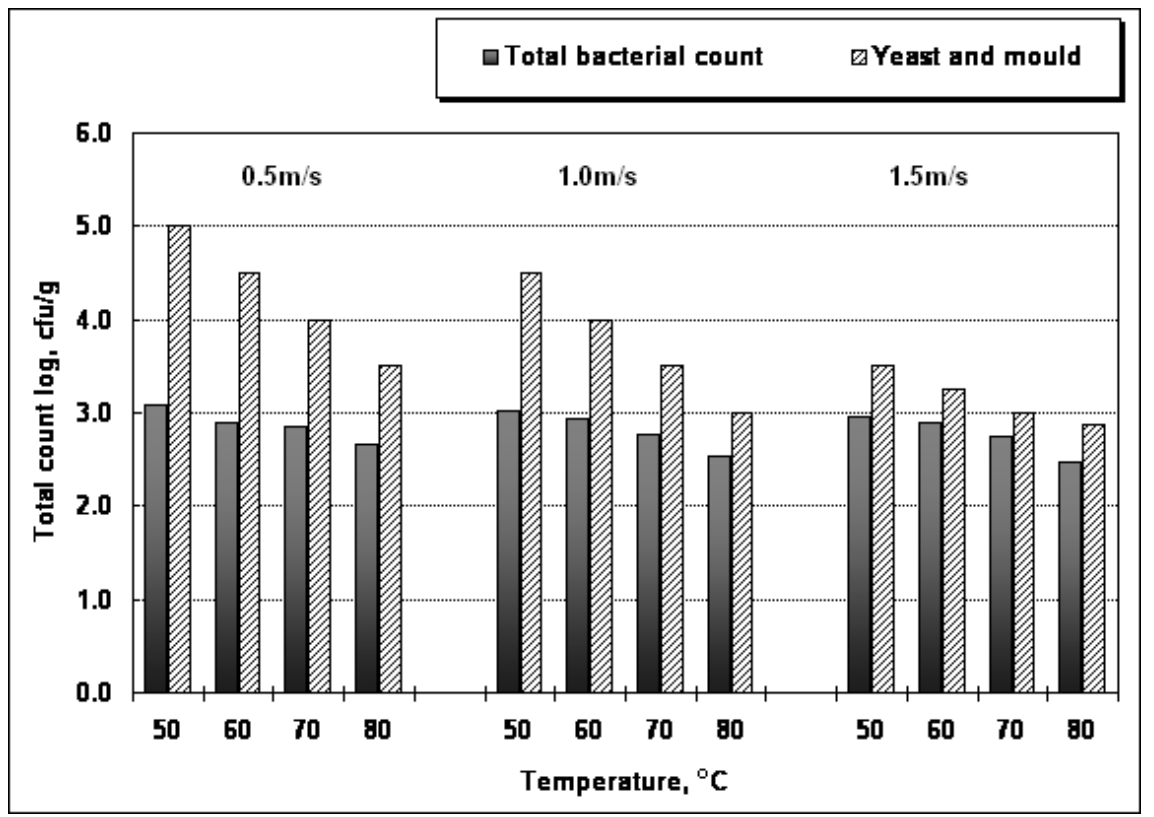

Fig. 6: Numbers of bacteria, yeast and mould in dried fish at different drying air temperature and air velocity.

\section{CONCLUSIONS}

The reduction rate of fish moisture content was increased with the increasing of drying air temperature and air velocity in all the drying conditions. Tilapia drying rate decreased continuously with the increasing of drying time and decreasing moisture content. The drying air temperature of $80^{\circ} \mathrm{C}$ and air velocity of $1.5 \mathrm{~m} / \mathrm{s}$ give the lower final moisture content of the dried fish in less time. Results of thin layer modeling shown that, the modified simple model could be used to explain moisture transfer in tilapia fish. This model could be used between drying air temperatures between 50 and $80^{\circ} \mathrm{C}$ and air velocities between 0.5 and $1.5 \mathrm{~m} / \mathrm{s}$. The estimated total cost of fish drying using the butane-gas dryer was $3.82 \mathrm{LE} / \mathrm{h}$. The final product had a microbial count below allowed level.

\section{REFERENCES}

Abila, R. O. (2003). Food Safety in Food Security and Food Trade: Case Study: Kenyan Fish Exports. 2020 Vision for Food, Agriculture 
PROCESS ENGINEERING

and Environment. International Food Policy Research Institute, Washington, DC, USA.

Akpinar, E.; Y. Bicer and F. Cetinkaya (2006). Modeling of thin layer drying of parsley leaves in convection drier and under open sun. J. of food Eng., 75: 308-315.

AOAC (2005). Official Methods of Analysis. AOAC., International, Maryland, USA.

APHA, American public health association (2001). Compendium of methods for the microbiological examination of foods. Washington DC., 4: 1219.

Bala, B. K. and M. R. A. Mondol (2001). Experimental investigation on solar drying of fish using solar tunnel dryer. Drying Technol., 19(2): 1-10.

Bellagha, S.; A. Sahli; A. Glenza and N. Kechaou (2005). Isohalic sorption isotherm of Sardine (Sardinella aurita): experimental determination and modeling. J. of Food Eng., 68: 105-111.

Bellagha, S.; E. Amami; A. Farhat and N. Kechaou (2002). Drying kinetics and characteristic drying curve of lightly salted Sardine (Sardinella aurita). Drying Technol., 20(7): 1527-1538.

Doungporn, S.; N. Poomsa-ad and L. Wiset (2012). Drying equations of Thai Hom Mali paddy by using hot air, carbon dioxide and nitrogen gases as drying media. Food Bioprod. Process., 90:187-198.

Duan, Z. H.; L. N. Jiang; J. L. Wang; X. Y. Yu and T. Wang (2011). Drying and quality characteristics of tilapia fish fillets dried with hot air-microwave heating. Food and Bioprod. processing. 89: 472476.

Duan, Z. H.; M. H. Yi and Z. G. Wang (2005). Processing technique of tilapia. Fish Sci Technol. Infor., 32(6): 250-252. 
Duan, Z. H.; M. Zhang and J. Tang (2004). Thin layer hot-air drying of bighead carp. Fisheries Sci., 23(3): 29-32.

Elmesery, H. S. (2008). Development and evaluation of mechanical dryer for drying figs. Unpublished Ph.D. Thesis, Department of Agric. Eng., Faculty of Agriculture, Kafrelsheikh University, Egypt.

FAO (1986). The production of fish meal and oil. Fisheries and aquaculture department. Food and Agric. organization of the united nations. FAO fisheries technical paper, 142-163.

Fatouh, M; M. Metwally; A. Helali and M. Shedid (2006). Herbs drying using a heat pump dryer. Energy Conversion and Management. 47: 26-29, 43.

Henderson, S and S. Pabis (1961). Grain drying theory. Temperature effect on drying coefficient. J. Agric. Eng. Res., 6(3): 169-174.

Hunt, D. (1983). Farm power and machinery management. $8^{\text {th }}$ Ed. Iowa State Univ. Press, Ames., USA, 59-76.

Jain, D. (2006). Determination of convective heat and mass transfer coefficients for solar drying of fish. Biosyst. Eng., 94(3): 429-435.

Jain, D. and P. B. Pathare (2007). Study the drying kinetics of open sun drying of fish, study the drying kinetics of open sun drying of fish. J. Food Eng., 78: 1315-1319.

Lagunas, S. M. C.; N. X. Zeng; T. K. Essert; T. D. Truong; C. Pina; J. S. Cullor; W. L. Smith and R. Larrain (2005). Disinfection of fishmeal with radiofrequency heating for improved quality and energy efficiency. J. of the Sci. of Food and Agric., 85: 2273-2280

Lewis, W. K. (1921). The rate of drying of solid materials. J. of Industrial Eng., 5(13): 427-433.

Li, J.; B. S. Li and W. Li (2009). Study on tilapia pickling technique. Modern Food Sci. Technol. 25 (6): 646-649. 
Mary, J. Z.; D. A. Power; S. M. Miller; G. E. Wilson and J. A. Johnson (2009). Manual of Microbiological Culture Media (Difco ${ }^{\mathrm{TM}}$ and BBL ${ }^{\text {TM }}$ Manual). Second Ed. USA.

Oyelese, O. A. (2006). Shelf life of tilapia fishmeal, paste and cake. J. Fish. Int., 1: 98-101.

Sobukola, O. P. and S. O. Olatunde (2011). Effect of salting techniques on salt uptake and drying kinetics of African catfish (Clarias gariepinus). Food and Bioproduct Processing, 89: 170-177.

Togrul, I. T. and D. Pehlivan (2004). Modeling of thin layer drying kinetics of some fruits under open-air sun drying process. J. of Food Eng., 65(3): 413-425.

USFDA, US Food Drug Adminstration (1998). Bacteriological Analytical Manuals. $8^{\text {th }}$ Edition, Revision A, AOAC International, Valsan AP, Gaithersburg MD, Nambiar,VN, Damle SD, Garg DK, Iyer SS (1985). In: Harvest and Post-harvest Technology of fish. Quality of dry nonpenarid of Bombay markets. 661-664.

Watanabe, W. O.; T. M. Losordo, and K. Fitzsimmons (2002). Tilapia production systems in the Americas, Technological advances, trends, and challenges. Rev Fish Sci., 10(3): 465-498.

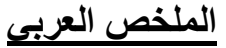

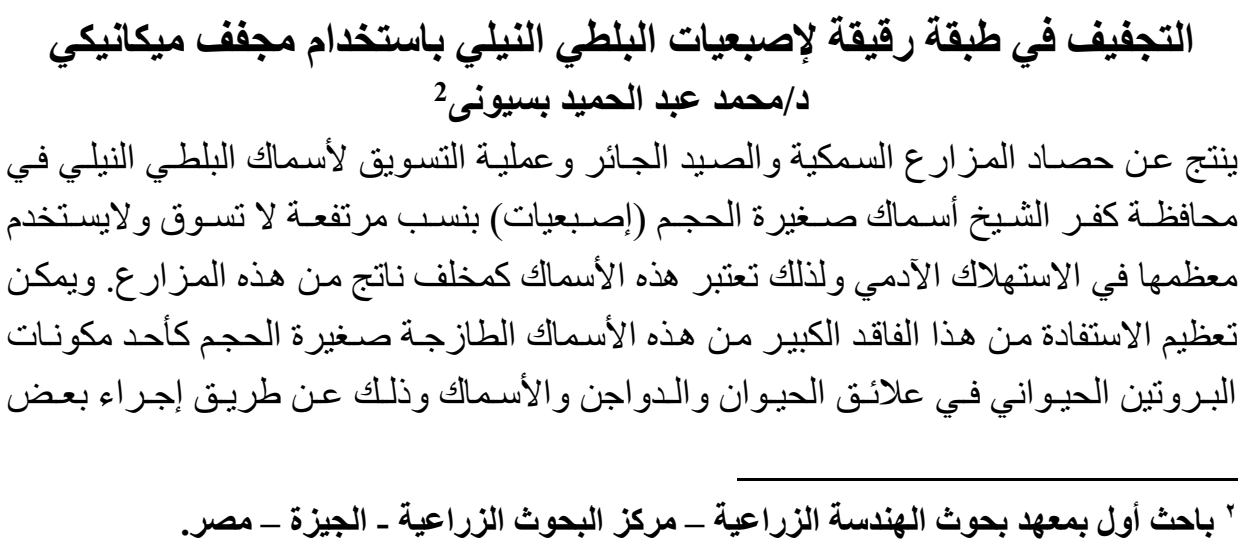


العمليات عليها كـالتجفيف و الطحن. لذلك الهدف من البحث در اسـة تجفيف إصبعيات البلطي

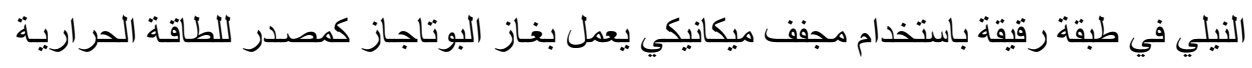

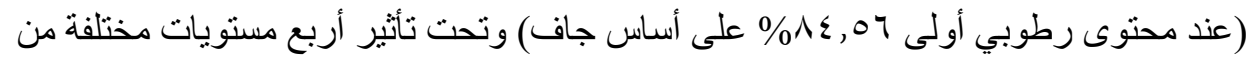

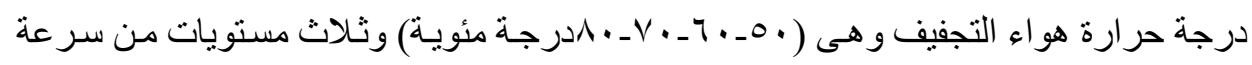

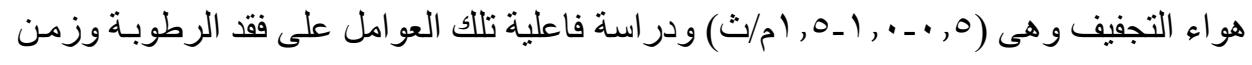
التجفيف ومعدل التجفيف ونسبة الرطوبة لإصبعيات البلطي. وقد تم اختبار ومقارنـة نموذجيين

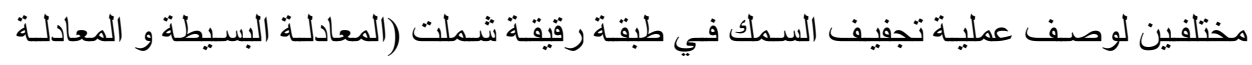
البسيطة المعدلة) تحت ظروف التشغيل المختلفة. كما تم تقدير تكاليف تشغيل المجفف و إجر اء

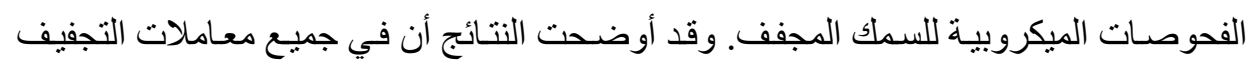
يزيد من معدل الانخفاض في المحتوى الرطوبي للسمك وكذا زيادة معدل التجفيف للسمك بزيـادة

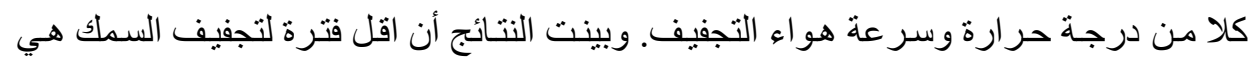

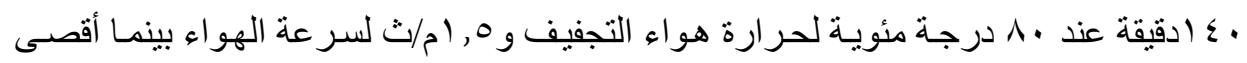

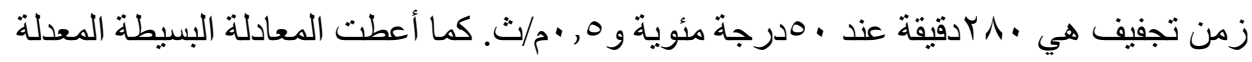
أعلى درجات الدقة في وصف سلوك التجفيف و التنبؤ بـالمحتوى الرطوبي للسـكك عند معـاملات

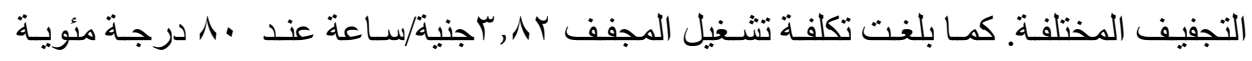

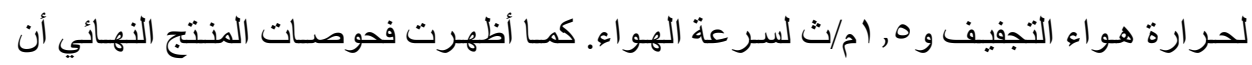
السمك المجفف آمن ميكروبيا تحت ظروف التجفيف المستخدمة. 